\title{
MATEMATIKA DALAM ARSITEKTUR: KONSEP SUSUNAN BILANGAN REAL DALAM KONSTRUKSI ATAP LOPO DI BENTENG NONE
}

\author{
Apridus Lapenangga ${ }^{1}$, Yohana Rowa ${ }^{2}$, Meryani Lakapu ${ }^{3}$ \\ 1. Program Studi Arsitektur, Fakultas Teknik, Universitas Katolik Widya Mandira, \\ Penfui, Kupang \\ 2,3. Program Studi Pendidikan Matematika, Fakultas Keguruan dan Ilmu Pendidikan, \\ Universitas Katolik Widya Mandira, Penfui, Kupang \\ Email: apriskefas@unwira.ac.id
}

\begin{abstract}
Abstrak
Benteng None merupakan benteng tradisional yang di dalamnya terdapat bangunan tradisional masyarakat Dawan, yakni Lopo dan Ume Kbubu. Salah satu Lopo pada area ini pernah terbakar dan belum dibangun kembali. Hal ini menjadi salah satu alasan penelitian ini dilakukan, yaitu untuk mengetahui elemen-elemen matematis pada konstruksi Lopo yang dapat bermanfaat sebagai panduan desain pada konstruksi bangunan Lopo lainnya. Penelitian ini bertujuan untuk menganalisis secara mendalam konsep susunan bilangan real pada konstruksi atap Lopo di Benteng None, sehingga metode yang digunakan adalah penelitian kualitatif dengan desain etnografi. Pembahasan ini dilakukan dengan menganalisis tiga elemen konstruksi pada atap Lopo, yakni: 5 lingkaran dalam, 26 lingkaran luar dan segiempat-segiempat pada atap Lopo. Sehingga, dapat disimpulkan bahwa beberapa elemen konstruksi pada atap Lopo yang dianalisis secara matematis menunjukkan adanya konsep susunan bilangan real. Dari pembahasan ini, diperoleh hasil yang menunjukkan adanya jenis-jenis susunan bilangan real, antara lain: Susunan bilangan real yang monoton turun, susunan bilangan real terbatas, susunan bilangan real dengan selisih tetap dan susunan bilangan real dengan selisih tidak tetap.
\end{abstract}

Kata kunci: konsep susunan bilangan real, konstruksi, Lopo.

\begin{abstract}
Title: Mathematics in Architecture: The Concept of Numbers in Roof Structure Construction of Fort None Lopo

Fort None is a traditional fortress in which there are traditional buildings of the Dawan people, namely Lopo and Ume Kbubu. One of the Lopo in this area was once burned and has not been rebuilt. This is one of the reasons this study was conducted, to find out the mathematical elements in Lopo construction which can be useful as a design guidelines for other Lopo building construction. This study aims to analyze in depth the concept of configuration of real numbers on the Lopo roof construction in Benteng None, so the method used is qualitative research with ethnographic design. This discussion is carried out by analyzing three construction elements on the Lopo roof, namely: 5 inner circles, 26 outer circles and rectangles on the Lopo roof. So, it can be concluded that some construction elements on the Lopo roof which are mathematically analyzed show the existence of the concept of real number configuration. From this discussion, the results show that there are types of real number configuration, including: Monotonic real numbers descending, finite real numbers, fixed real numbers with fixed differences and real numbers with non-fixed differences.
\end{abstract}

Keywords: the concept of real numbers configuration, construction, Lopo. 


\section{Pendahuluan}

Kabupaten Timor Tengah Selatan (TTS) yang beribukota Soe adalah salah satu kabupaten di propinsi Nusa Tenggara Timur (NTT) yang terletak di pulau Timor pada ketinggian \pm 790 mdpl, sehingga udara di kota inipun terasa sejuk dan pada bulan-bulan tertentu akan sangat dingin. Kabupaten ini memiliki potensi pariwisata yang beragam, mulai dari wisata alam (Cagar Alam Mutis dan Wisata Air Tejun Oehala), hingga wisata budaya (Kampung Adat Boti, Situs Benteng None, dan lain-lain). Karena jaraknya yang kurang lebih $20 \mathrm{~km}$ dari kota Soe dan berada tidak jauh dari lintasan jalan propinsi sehingga pada beberapa tahun terakhir ini Benteng None menjadi salah satu destinasi wisata baru yang sering dikunjungi.

Sebagai destinasi wisata budaya, Benteng None memiliki ciri khas yaitu menampilkan atraksi-atraksi budaya berupa beberapa jenis tarian tradisional serta rumah tradisional masyarakat Dawan yang dikelilingi oleh susunan batu yang sudah ada sejak benteng ini dibangun. Benteng ini adalah sebuah benteng tradisional dari suku Amanuban (salah satu dari 3 suku masyarakat Dawan di kabupaten TTS). Raja Amanuban membangun benteng ini untuk menghalau musuh dalam perang suku. Secara turun-temurun benteng ini dijaga oleh keluarga Tauho dan pada saat sekarang berada dibawah tanggung jawab Bapak Anderias Tauho.

Peninggalan pada situs ini berupa 2 buah Lopo (pendopo dan tempat penyimpanan cadangan makanan), 2 buah Ume Kbubu (rumah tradisional yang sering disebut rumah bulat) dan pagar batu (Lakapu \& Lapenangga,
2019). Bangunan tradisional yang terdapat dalam area benteng yang sudah dijaga turun temurun yaitu 2 buah Lopo dan 2 buah Ume Kbubu. Di sisi timur, 1 Ume Kbubu dan 1 Lopo yang pernah terbakar dan pada tahun 2017. Ume Kbubu tersebut baru berhasil dibangun kembali, sedangkan bangunan Lopo belum dibangun kembali. Salah satu alasan penelitian ini dilakukan adalah untuk mengetahui elemen-elemen matematis pada konstruksi Lopo yang dapat bermafaat sebagai panduan desain pada konstruksi bangunan Lopo lainya.

Lopo adalah bangunan tradisional yang berfungsi sebagai lumbung penyimpanan bahan makanan dan tempat penyimpanan beberapa benda pusaka. Dalam bahasa Dawan, Lopo atau Ume Lopo berarti rumah tempat musyawarah atau tempat pertemuan umum (Saraswati, 2016). Lopo sering disebut bangunan laki-laki yang umumnya digunakan untuk menerima tamu, berupa pendopo yang terbuka, tidak berdinding dan berada di depan Ume Kbubu. Rumah Lopo (Uim Lopo) memiliki fungsi antara lain sebagai tempat tinggal, tempat menerima tamu, tempat mendidik anak, tempat sembahyang keluarga, tempat upacara, tempat demokrasi (musyawarah mufakat dalam keluarga), tempat menyimpan bahan makanan, tempat menyimpan barang pusaka, tempat berteduh, tempat makan, tempat tidur, tempat merawat orang sakit dan tempat melindungi diri dari hujan (Benu \& Rafael, 2019). Bangunan ini berbentuk bulat dengan bagian dasar terdiri dari susunan batu yang disusun bertumpuk membentuk tabung.

Konstruksi bangunan ditopang oleh 4 tiang utama yang ditanam langsung ke tanah. Empat tiang ini berfungsi 
memikul 2 balok utama yang di atasnya terdapat beberapa balok anak untuk menopang lantai loteng yang terdiri dari bilah-bilah kayu yang disusun rapat. Lantai loteng ini berbentuk lingkaran yang tepat dikelilingi oleh sisi atap. Pada bagian loteng terdapat 1 tiang utama, berada pada titik tengah lantai loteng dan berfungsi sebagai penopang atap.

Konstruksi atap berupa kerucut yang terbentuk dari rusuk-rusuk tegak dengan bagian puncaknya terhubung pada 1 titik tepat di atas tiang utama. Bentuk bulat kerucut terbentuk dari 5 ikatan utama, ikatan pertama mengunci bagian tengah rusuk-rusuk atap yang sejajar dengan lantai loteng, ikatan yang lain bersusun ke atas dan ikatan terakhir sebagai pengunci titik temu rusuk atap dekat dengan ujung tiang bubungan. Reng pada atap juga membentuk lingkaran yang diikat mengelilingi rusuk atap dan bersusun dari dasar atap hingga puncak atap.

Seperti penjelasan di atas bahwa elemen-elemen konstruksi bangunan Lopo membentuk adanya bidangbidang datar maupun bangun-bangun ruang yang dapat dijelaskan secara matematis. Beberapa bidang datar yang terbentuk dapat dijelaskan secara matematis. Garis keliling lingkaran pada reng yang tersusun dari dasar ke puncak atap dan memotong garis rusuk atap akan membentuk bidang-bidang segi empat dengan pengulangan yang berbeda dan dapat dijelaskan secara matematis. Selain itu, lingkaranlingkaran dalam dan luar pada atap Lopo, dapat pula dinyatakan secara matematis dalam hal ini dapat dinyatakan dengan himpunan bilangan. Dari himpunan-himpunan bilangan yang telah diketahui, dapat dibentuk suatu susunan bilangan (Salamah,
2019). Dengan demikian, setiap perubahan ukuran dari tiap segi empat dan lingkaran yang tersusun pada atap dapat dinyatakan secara matematis menggunakan konsep susunan bilangan real.

\section{Metode}

Penelitian ini bertujuan untuk menganalisis secara mendalam konsep susunan bilangan real pada konstruksi atap Lopo di Benteng None, sehingga jenis penelitian yang digunakan adalah penelitian kualitatif dengan desain etnografi. Dalam tulisan ini, konsep yang dianalisis adalah konsep susunan bilangan real sesuai dengan informasi kualitatif yang diperoleh dari hasil wawancara dan pengukuran beberapa elemen konstruksi pada atap Lopo.

Langkah pertama yang dilakukan adalah menentukan obyek penelitian yakni rumah Lopo pada Benteng None. Lopo dipilih karena merupakan salah satu dari rumah tradisional masyarakat Dawan dan obyek Lopo dianalisis untuk menghitung elemen-elemen konstruksi secara matematis untuk kebutuhan rekonstruksi bangunan Lopo yang pernah terbakar sebelumnya pada lokasi tersebut. Setelah penentuan obyek kemudian dilakukan survei awal agar dari hasil survei ini dapat ditentukan topik penelitian.

Tahap berikutnya adalah pengumpulan data dengan melakukan wawancara dan pengukuran obyek (bangunan Lopo). Hasil wawancara dan pengukuran kemudian dianalisis secara matematis untuk menghitung selisih diameter lingkaran dalam dan luar, serta menghitung keliling segi empatsegi empat yang merupakan bagian dari selimut kerucut pada atap Lopo. Hasil penelitian ini berupa jenis-jenis susunan bilangan real. Secara umum 
prosedur dalam penelitian ini dinyatakan dalam gambar berikut ini:

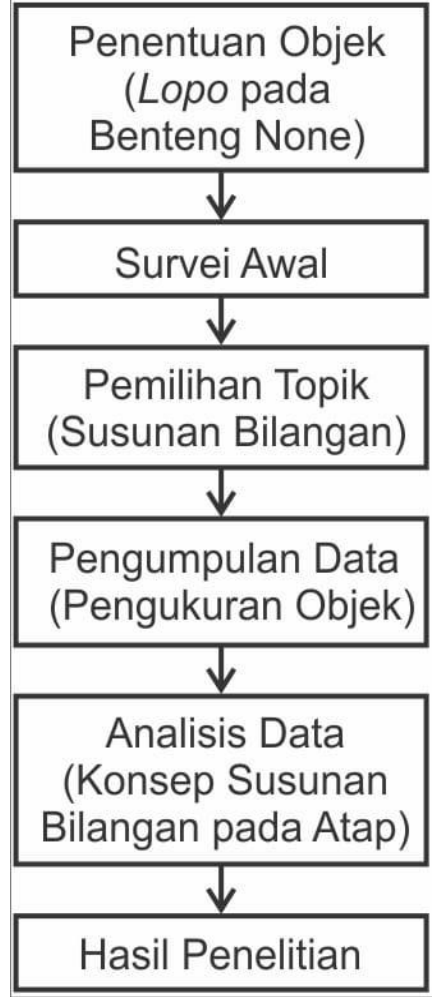

Gambar 1. Alur penelitian Sumber: Analisis penulis, 2020

\section{Hasil dan Pembahasan}

Di bawah ini adalah gambar asli dan penampang rumah Lopo sebagai obyek yang dianalisis dalam penelitian ini.

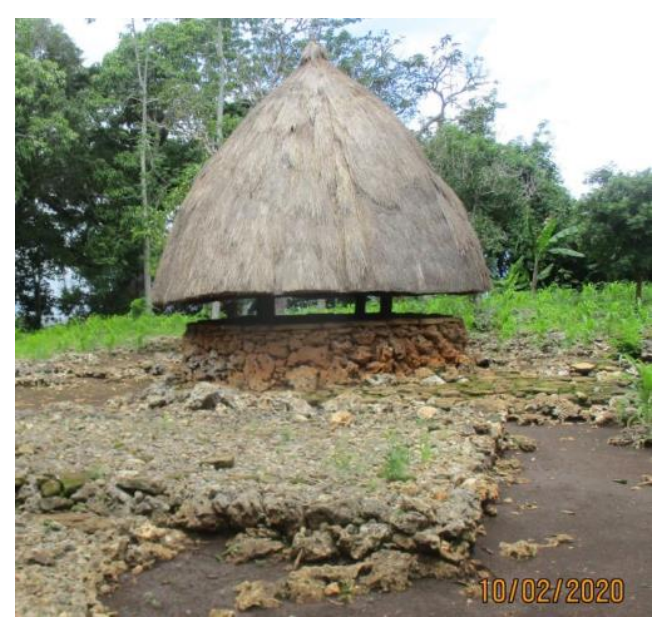

Gambar 2. Lopo di Benteng None Sumber: Hasil survei, 2020

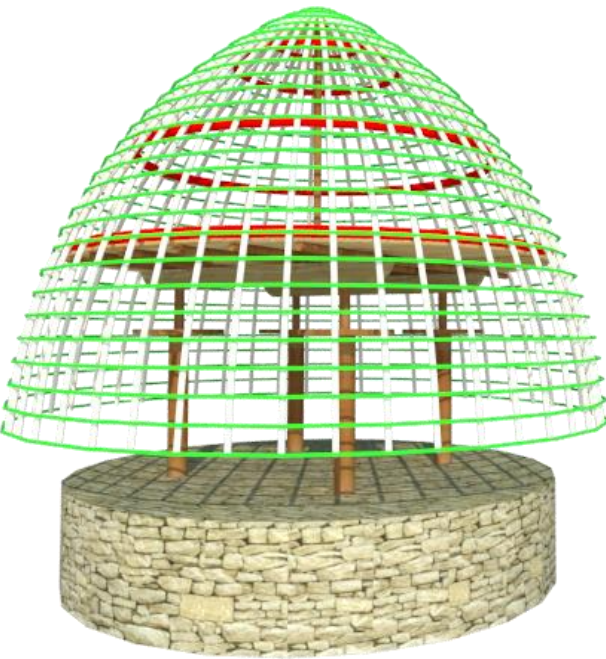

Gambar 3. Penampang Lopo di Benteng None

Sumber: Hasil survei, 2020

Dalam mengkonstruksi suatu bangunan, tanpa disadari masyarakat tradisional telah menerapkan nilai-nilai matematika dalam proses konstruksi. Salah satu contohnya adalah Lopo yang ada di Benteng None. Dalam membangun Lopo tersebut, masyarakat telah menerapkan beberapa konsep susunan bilangan real.

Berikut ini adalah hasil analisis mengenai konsep susunan bilangan real yang ditemukan dalam bangunan tradisional (Lopo) di Benteng None. Semua nilai pengukuran dan perhitungan menggunakan satuan meter.

\section{Lima Buah Lingkaran Dalam pada Atap Lopo}

Di bawah ini adalah gambar 5 buah lingkaran dalam yang terdapat pada atap Lopo: 


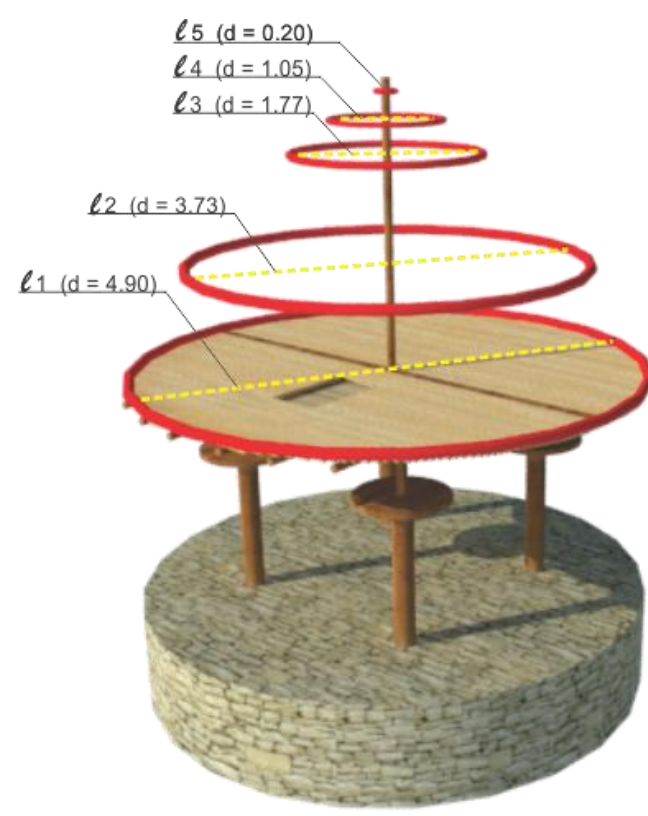

Gambar 4. Diameter $(d)$ lingkaran dalam Sumber: Hasil survei, 2020

Diameter-diameter pada lingkaran dalam, dapat ditulis dalam bentuk susunan bilangan real seperti di bawah ini:

$A=(4,9 ; 3,73 ; 1,77 ; 1,05 ; 0,2)$

Susunan bilangan real $A$ secara matematis, dapat dinyatakan sebagai:

1).Susunan bilangan real yang monoton turun karena memenuhi ketaksamaan:

$u_{1}>u_{2}>u_{3}>u_{4}>u_{5}$, dengan

$u_{1}=4,9 ; u_{2}=3,73 ; u_{3}=1,77$;

$u_{4}=1,05$ dan $u_{5}=0,2$

2).Susunan bilangan real terbatas karena susunan bilangan real $A$ memiliki batas atas yaitu 4,9 dan batas bawah yaitu 0,2 .

3). Susunan bilangan real dengan selisih tidak tetap

Secara matematis, selisih dari dua suku yang berdekatan dapat ditulis sebagai berikut:

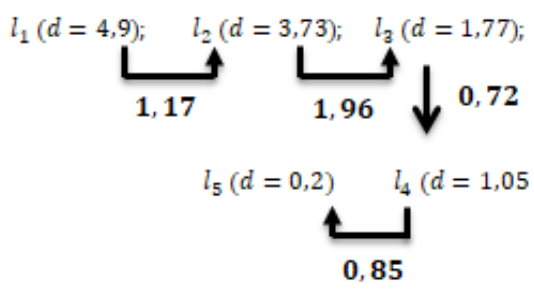

Misalnya:

$u_{1}=4,9 ; u_{2}=3,73 ; u_{3}=1,77$;

$u_{4}=1,05 ;$ dan $u_{5}=0,2$

maka dapat ditulis sebagai berikut:

$u_{2}=u_{1}-1,17 ; \quad u_{4}=u_{3}-0,72$;

$u_{3}=u_{2}-1,96 ; \quad u_{5}=u_{4}-0,85$

Uraian di atas menunjukkan bahwa selisih dari dua suku yang berdekatan, tidak tetap.

\section{Dua Puluh Enam Buah Lingkaran Luar pada Atap Lopo}

Berikut ini adalah gambar 26 buah lingkaran luar yang terdapat pada atap Lopo:

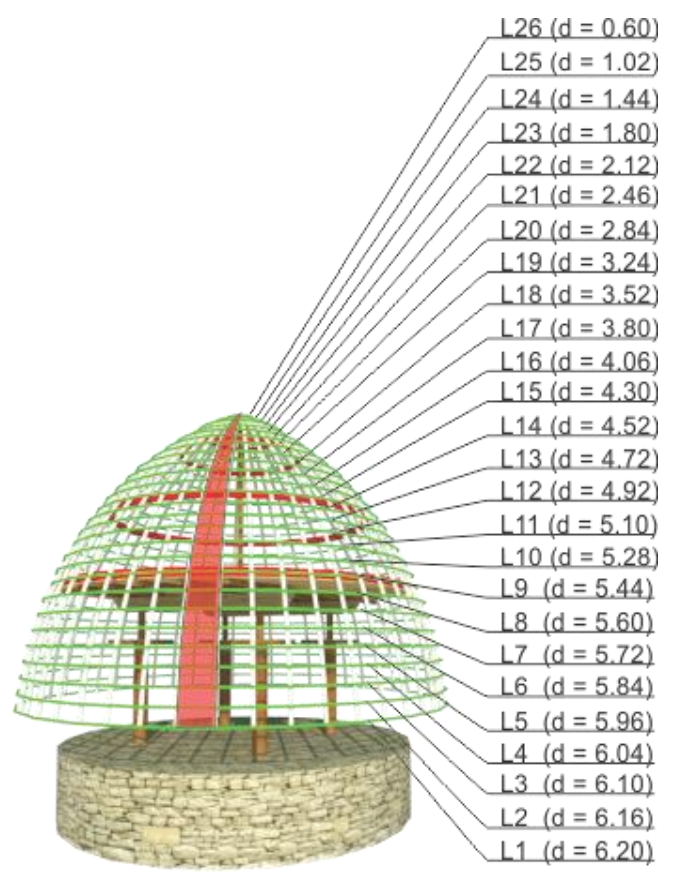

Gambar 5. Diameter $(d)$ lingkaran luar Sumber: Hasil survei, 2020

Diameter-diameter pada lingkaran luar dapat disajikan dalam bentuk susunan bilangan real sebagai berikut: 
$B=(6,2 ; 6,16 ; 6,1 ; 6,04 ; 5,96 ; 5,84$;

5,$72 ; 5,6 ; 5,44 ; 5,28 ; 5,1 ; 4,92$;

4,$72 ; 4,52 ; 4,3 ; 4,06 ; 3,8 ; 3,52$;

3,$24 ; 2,84 ; 2,46 ; 2,12 ; 1,8$;

$1,44 ; 1,02 ; 0,6)$

Susunan bilangan real $B$ secara matematis, dapat dinyatakan sebagai:

1).Susunan bilangan real yang monoton turun karena memenuhi ketaksamaan:

$u_{1}>u_{2}>u_{3}>\cdots>u_{26}$

dengan

$u_{1}=6,2 ; u_{2}=6,16 ; \ldots$;

$u_{13}=4,72 ; u_{14}=4,52 ; \ldots$;

$u_{26}=0,6$

2).Susunan bilangan real terbatas karena susunan bilangan real $B$ memiliki batas atas yaitu 6,2 dan batas bawah yaitu 0,6 .

$3)$.Susunan bilangan real dengan selisih tetap dan tidak tetap

Secara matematis, selisih dari dua suku yang berdekatan dapat ditulis sebagai berikut:

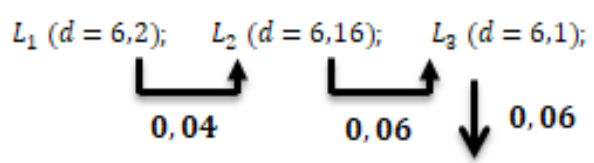

$\mathbf{0 , 1 2 \downarrow}$

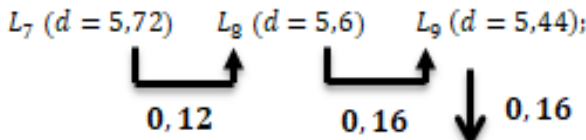

$L_{12}(d=4,92) ; \quad L_{11}(d=5,1) ; \quad L_{10}(d=5,28)$;

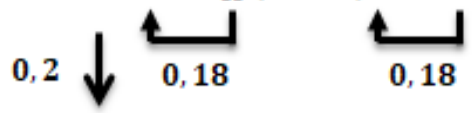

$L_{13}(d=4,72) ; \quad L_{14}(d=4,52) ; \quad L_{15}(d=4,3) ;$

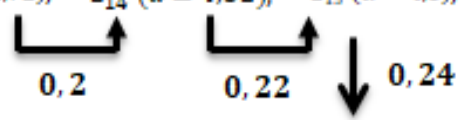

$L_{18}(d=3,52) ; \quad L_{17}(d=3,8) ; \quad L_{16}(d=4,06)$;

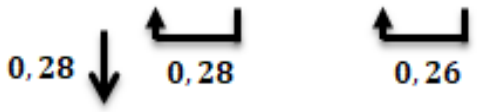

$L_{\mathbf{0}, 4}(d=3,24) ; \quad L_{20}(d=2,84) ; \quad \underbrace{L_{21}}_{\mathbf{0 , 3 8}}(d=2,46) ;$

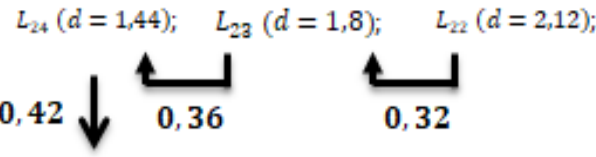

$L_{25}(d=1,02) ; \quad L_{\mathbf{0 , 4 2}}^{L_{26}}(d=0,6)$

Misalnya,

$u_{1}=6,2 ; u_{2}=6,16 ; . . ; u_{13}=4,72$;

$u_{14}=4,52 ; \ldots ; u_{26}=0,6$,

maka dapat ditulis sebagai berikut:

$\begin{array}{ll}u_{2}=u_{1}-0,04 ; & u_{15}=u_{14}-0,22 ; \\ u_{3}=u_{2}-0,06 ; & u_{16}=u_{15}-0,24 ; \\ u_{4}=u_{3}-0,06 ; & u_{17}=u_{16}-0,26 ; \\ u_{5}=u_{4}-0,08 ; & u_{18}=u_{17}-0,28 ; \\ u_{6}=u_{5}-0,12 ; & u_{19}=u_{18}-0,28 ; \\ u_{7}=u_{6}-0,12 ; & u_{20}=u_{19}-0,4 ; \\ u_{8}=u_{7}-0,12 ; & u_{21}=u_{20}-0,38 ; \\ u_{9}=u_{8}-0,16 ; & u_{22}=u_{21}-0,34 ; \\ u_{10}=u_{9}-0,16 ; & u_{23}=u_{22}-0,32 ; \\ u_{11}=u_{10}-0,18 ; & u_{24}=u_{23}-0,36 ; \\ u_{12}=u_{11}-0,18 ; & u_{25}=u_{24}-0,42 ; \\ u_{13}=u_{12}-0,2 ; & u_{26}=u_{25}-0,42 ; \\ u_{14}=u_{13}-0,2 ; & \end{array}$


Uraian di atas menunjukkan bahwa selisih dari beberapa suku yang berdekatan ada yang bersifat tetap dan ada yang bersifat tidak tetap. Sukusuku yang berselisih tetap, misalnya $\left(u_{2}, u_{3} \quad \& \quad u_{3}, u_{4}\right) ;\left(u_{5}, u_{6} ; u_{6}\right.$, $\left.u_{7} \& u_{7}, u_{8}\right)$; dan yang lainnya adalah suku-suku yang berselisih tidak tetap, misalnya $\left(u_{1}, u_{2} \& u_{2}, u_{3}\right)$; ( $u_{3}$, $u_{4} \& u_{4}, u_{5}$ ); dan yang lainnya.

\section{Segitiga-Segitiga pada Atap Lopo}

Diasumsikan: dua buah rusuk atau suaf pada atap Lopo dan $\frac{1}{n}$ bagian dari keliling lingkaran dapat membentuk sebuah segitiga. Berikut ini adalah gambar segitiga-segitiga yang terdapat pada atap Lopo:

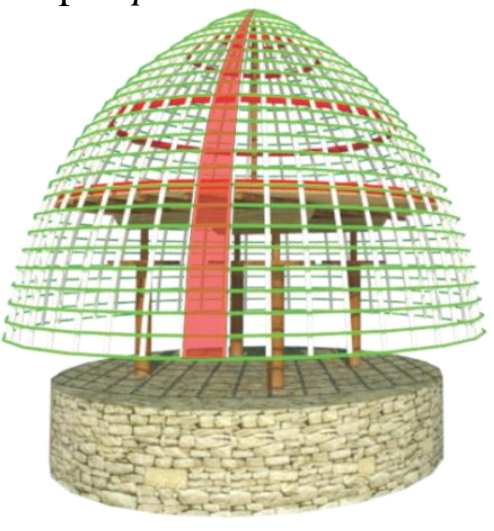

Gambar 6. Segitiga pada atap Lopo Sumber: Hasil survei, 2020

Dari survei yang dilakukan, diperoleh data sebagai berikut:

1). Segitiga yang terbentuk dari dua buah rusuk atau suaf dan $\frac{1}{n}$ dari keliling lingkaran 1 berjumlah 44 buah dan ke-44 segitiga tersebut diasumsikan memiliki ukuran yang sama. $(n=44)$

2). Di dalam setiap segitiga tersebut terdapat 25 buah segi empat berbeda dan 1 buah segitiga (gambar 7). Ke-25 buah segi empat tersebut memiliki lebar yang sama yaitu 0,2 meter dan panjang yang berbeda-beda.
3). Berdasarkan $a$ ) dan $b$ ), total segi empat dan segitiga berbeda yang terdapat pada atap Lopo secara berturut-turut adalah 1100 dan 44 buah. Oleh karena itu, luas selimut kerucut (atap Lopo) dapat dihitung dengan menjumlahkan keliling dari 1144 buah bangun datar (segi empat dan segitiga) yang terdapat pada atap Lopo.

4). Diameter lingkaran-lingkaran luar pada atap Lopo adalah:

$\left(d L_{1}=6,2 ; d L_{2}=6,16 ; \ldots\right.$;

$\left.d L_{26}=0,6\right)($ Dapat dilihat pada Gambar 5).

Berdasarkan data di atas, maka dapat dihitung keliling setiap segi empat yang terdapat pada satu buah segitiga.

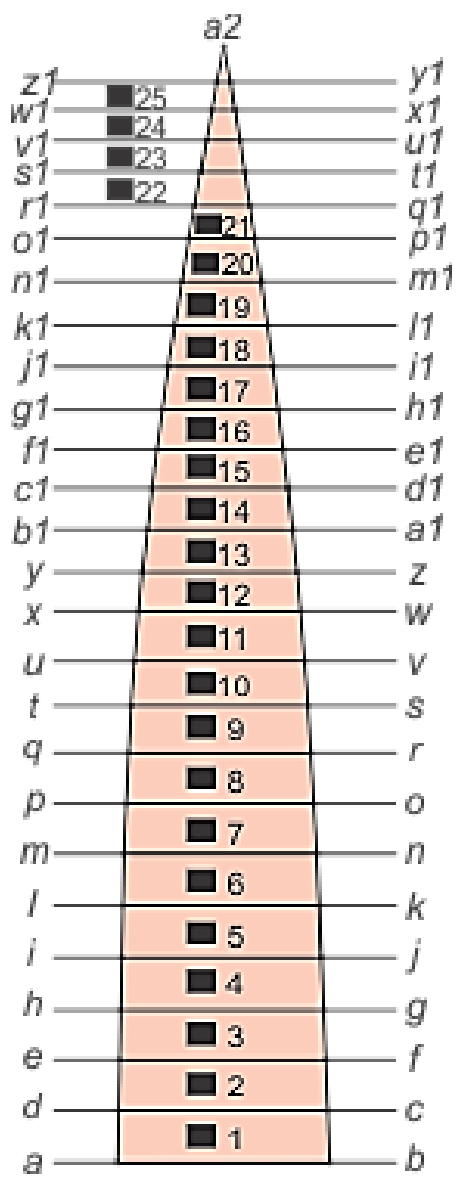

Gambar 7. Salah satu segitiga yang terdapat pada atap

Sumber: Hasil survei, 2020 
Berikut ini adalah perhitungan keliling setiap segi empat:

1). Untuk menghitung keliling segi empat pertama $\left(K \mathbf{m}_{1}\right)$

Diketahui:

$d L_{1}=6,2$

$d L_{2}=6,16$

$b c=a d=0,2$

Ditanya: $K \mathbf{m}_{1}$ ?

Dijawab:

$$
\begin{array}{rlc}
a b & = & \frac{K L_{1}}{\text { banyaknya segitiga }} \\
& = & \frac{\pi \times d L_{1}}{43} \\
& = & \frac{3,14 \times 6,2}{43} \\
a b & = & 0,4527 \\
d c & = & \frac{K L_{2}}{43} \\
& = & \frac{\pi L_{2}}{43} \times 6,16 \\
& = & 0,4498 \\
d c & = & \\
K \mathbf{\square}_{1} & = & a b+b c+d c+a d \\
& = & 0,4527+0,2+0,4498+0,2 \\
& = & 1,3025
\end{array}
$$

Jadi, keliling segi empat pertama $\left(K \mathbf{\varpi}_{1}\right)$ adalah 1,3025 .

2). Untuk menghitung keliling segi empat kedua $\left(K \mathbf{m}_{2}\right)$

Diketahui:

$d L_{3}=6,1$

$d c=0,4498$

$c f=d e=0,2$

Ditanya: $K \mathbf{m}_{2}$ ?

Dijawab:

$$
\begin{aligned}
& \text { ef }=\frac{K L_{3}}{\text { banyaknya segitiga }} \\
& =\frac{\pi \times d L_{3}}{43}
\end{aligned}
$$

$$
\begin{array}{rlc} 
& = & \frac{3,14 \times 6,1}{43} \\
\text { ef } & = & 0,4452 \\
K \mathbf{m}_{2}= & d c+c f+e f+d e \\
& = & 0,4498+0,2+0,4454+0,2 \\
K \mathbf{m}_{2} & = & 1,2952
\end{array}
$$

Jadi, keliling segi empat kedua $\left(K \mathbf{m}_{2}\right)$ adalah 1,2952.

3). Untuk menghitung keliling segi empat ketiga $\left(K \mathbf{m}_{3}\right)$

Diketahui:

$$
\begin{aligned}
& d L_{4}=6,04 \\
& \text { ef }=0,4452 \\
& f g=e h=0,2 \\
& \text { Ditanya: } \mathrm{K}_{3} \text { ? } \\
& \text { Dijawab: } \\
& \begin{array}{rlc}
h g & = & \frac{K L_{4}}{\text { banyaknya segitiga }} \\
& = & \frac{\pi \times d L_{4}}{43} \\
& = & \frac{3,14 \times 6,04}{43} \\
h g & = & 0,4411 \\
K \mathbf{\square}_{3} & = & e f+f g+h g+e h \\
& = & 0,4452+0,2+0,4411+0,2 \\
K \mathbf{\square}_{3} & = & 1,2863
\end{array}
\end{aligned}
$$

Jadi, keliling segi empat ketiga $\left(K \mathbf{m}_{3}\right)$ adalah 1,2863 .

4). Dengan cara yang sama, maka akan diperoleh nilai dari $K \mathbf{\square}_{4}, K \mathbf{\square}_{5}, K \mathbf{\square}_{6}, \ldots, K \mathbf{\square}_{25}, \quad$ seperti di bawah ini:

$$
\begin{array}{ll}
K \mathbf{\square}_{4}=1,2763 & K \mathbf{\square}_{15}=1,0105 \\
K \mathbf{\square}_{5}=1,2617 & K \mathbf{\square}_{16}=0,974 \\
K \mathbf{\square}_{6}=1,2389 & K \mathbf{\square}_{17}=0,9345 \\
K \mathbf{\square}_{7}=1,2213 & K \mathbf{\square}_{18}=0,8936 \\
K \mathbf{\square}_{8}=1,2061 & K \mathbf{\square}_{19}=0,844 \\
K \mathbf{\square}_{9}=1,1828 & K \mathbf{\square}_{20}=0,787 \\
K \mathbf{\square}_{10}=1,158 & K \mathbf{\square}_{21}=0,7344 \\
K \mathbf{\square}_{11}=1,1317 & K \mathbf{q}_{22}=0,6862 \\
K \mathbf{\square}_{12}=1,104 & K \mathbf{q}_{23}=0,6366
\end{array}
$$




$$
\begin{array}{ll}
K \mathbf{\square}_{13}=1,0748 & K \mathbf{\square}_{24}=0,5797 \\
K \mathbf{\square}_{14}=1,0441 & K \mathbf{\square}_{25}=0,5183
\end{array}
$$

Diameter-diameter pada lingkaran luar, dapat disajikan dalam bentuk susunan bilangan real sebagai berikut:

$$
\begin{aligned}
& C=(1,3025 ; 1,2952 ; 1,2863 \text {; } \\
& 1,2763 ; 1,2617 ; 1,2389 \text {; } \\
& 1,2213 ; 1,2061 ; 1,1828 \text {; } \\
& 1,158 ; 1,1317 ; 1,104 \text {; } \\
& 1,0748 ; 1,0441 ; 1,0105 \text {; } \\
& 0,974 ; 0,9345 ; 0,8936 \text {; } \\
& 0,844 ; 0,787 ; 0,7344 \text {; } \\
& 0,6862 ; \quad 0,6366 ; 0,5797 \\
& 0,5183 \text { ) }
\end{aligned}
$$

Susunan bilangan real $C$ secara matematis, dapat dinyatakan sebagai:

1). Susunan bilangan real yang monoton turun karena memenuhi ketaksamaan:

$u_{1}>u_{2}>u_{3}>\cdots>u_{25}$,

dengan

$u_{1}=1,3025 ; u_{2}=1,2952 ; \ldots$;

$u_{13}=1,0748 ; \ldots ; \quad u_{25}=0,5183$

2). Susunan bilangan real yang terbatas karena susunan bilangan real $C$ memiliki batas atas yaitu 1,3025 dan batas bawah yaitu 0,5183 .

3). Susunan bilangan real dengan selisih tidak tetap

Secara matematis, selisih dari dua suku yang berdekatan dapat ditulis sebagai berikut:
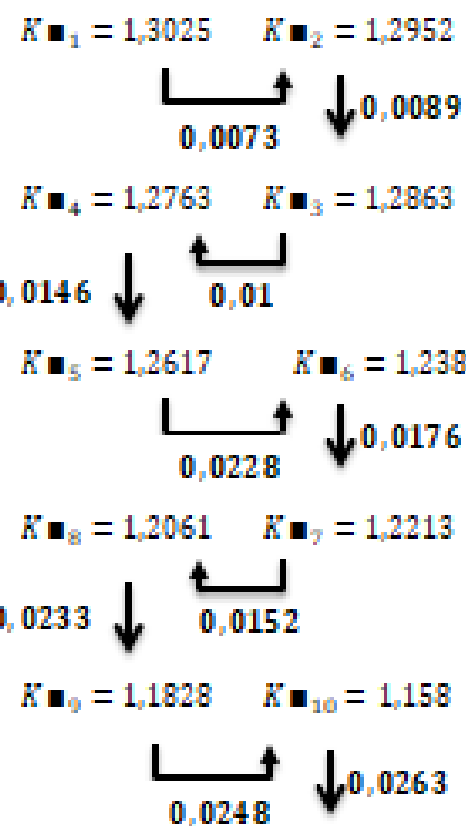

$K \mathbf{\square}_{12}=1,104 \quad K \mathbf{m}_{11}=1,1317$

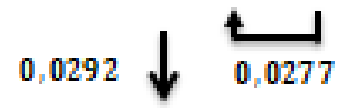

$K \mathbf{m}_{13}=1,0748 \quad K \mathbf{m}_{14}=1,0441$

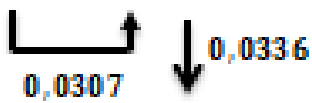

$K \mathbf{m}_{16}=0,974 \quad K \mathbf{\varpi}_{15}=1,0105$

$0,0395 \downarrow \underset{0,0365}{\longleftarrow}$

$K \mathbf{m}_{17}=0,9345 \quad K \mathbf{m}_{18}=0,8936$

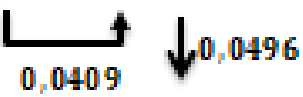

$K \mathbf{m}_{20}=0,787 \quad K \mathbf{m}_{19}=0,844$

$0,0526 \downarrow \underset{0,057}{\longleftarrow}$

$K \mathbf{m}_{21}=0,7344 \quad K \mathbf{m}_{22}=0,6862$

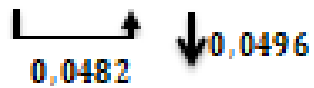

$K \mathbf{m}_{24}=0,5797 \quad K \mathbf{m}_{23}=0,6366$

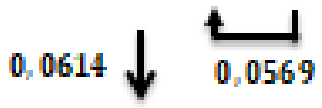

$K \mathbf{m}_{25}=0,5183$ 
Misalnya,

$u_{1}=1,3025 ; u_{2}=1,2952 ; \ldots ;$
$u_{13}=1,0748 ; \ldots ; \quad u_{25}=0,5183$,
maka dapat ditulis sebagai berikut:

$$
\begin{aligned}
& u_{2}=u_{1}-0,0073 ; \\
& u_{3}=u_{2}-0,0089 ; \\
& u_{4}=u_{3}-0,01 ; \\
& u_{5}=u_{4}-0,0146 ; \\
& u_{6}=u_{5}-0,0228 ; \\
& u_{7}=u_{6}-0,0176 ; \\
& u_{8}=u_{7}-0,0152 ; \\
& u_{9}=u_{8}-0,0233 ; \\
& u_{10}=u_{9}-0,0248 ; \\
& u_{11}=u_{10}-0,0263 ; \\
& u_{12}=u_{11}-0,0277 ; \\
& u_{13}=u_{12}-0,0292 ; \\
& u_{14}=u_{13}-0,0307 ; \\
& u_{15}=u_{14}-0,0336 ; \\
& u_{16}=u_{15}-0,0365 ; \\
& u_{17}=u_{16}-0,0395 ; \\
& u_{18}=u_{17}-0,0409 ; \\
& u_{19}=u_{18}-0,0496 ; \\
& u_{20}=u_{19}-0,057 ; \\
& u_{21}=u_{20}-0,0526 ; \\
& u_{22}=u_{21}-0,0482 ; \\
& u_{23}=u_{22}-0,0496 ; \\
& u_{24}=u_{23}-0,0569 ; \\
& u_{25}=u_{24}-0,0614
\end{aligned}
$$

Berdasarkan uraian di atas, dapat dianalisis bahwa untuk setiap dua suku yang berdekatan selisihnya bersifat tidak tetap. Misalnya $\left(u_{2}, u_{3}\right.$ \& $\left.u_{3}, u_{4}\right) ;\left(u_{4}, u_{5} ; \& u_{5}, u_{6}\right)$; dan yang lainnya.

Secara umum, konsep matematika yang ditemukan di beberapa elemen konstruksi pada atap Lopo yang dianalisis adalah konsep mengenai susunan bilangan real. Adapun jenis susunan bilangan real yang dimaksud yaitu:

1). Susunan bilangan real yang monoton turun

Susunan bilangan real $A, B$ dan $C$ dikatakan susunan bilangan monoton turun karena memenuhi ketaksamaan:

$u_{1} \geq u_{2} \geq u_{3} \geq \ldots \geq u_{n}$
2).Susunan bilangan real yang terbatas

Susunan bilangan real $A, B$ dan $C$ dikatakan susunan bilangan real terbatas karena memiliki batas atas dan batas bawah.

3). Susunan bilangan real dengan selisih tidak tetap

Susunan bilangan real $A$ dan $C$ adalah susunan bilangan dengan selisih tidak tetap, sedangkan susunan bilangan real $B$ dapat dipecah menjadi susunan bilangan dengan selisih tidak tetap dengan mengambil beberapa suku pada susunan tersebut.

4). Susunan bilangan real dengan selisih tetap

Susunan bilangan real $B$ dapat dipecah menjadi beberapa susunan yang berselisih tetap.

Selain itu, suku-suku pada susunan bilangan real $A, B$ dan $C$ memenuhi sifat trikotomi pada bilangan real, yaitu: jika $x$ dan $y$ adalah bilanganbilangan, maka pasti satu di antara yang berikut, berlaku: $x<y, x>y$ dan $x=y$ CITATION Var10 l 1057 (Varberg \& Purcell, 2010).

Dalam hal ini, setiap dua suku yang berdekatan pada ketiga susunan bilangan tersebut, memenuhi $u_{n}>$ $u_{n+1}$.

Susunan-susunan bilangan real yang disusun dari elemen-elemen konstruksi pada atap Lopo tidak dapat disebut sebagai barisan bilangan real, karena tidak memiliki pola pengulangan tertentu atau bukan merupakan suatu fungsi. Hal ini didukung oleh pernyataan bahwa suatu barisan dapat dispesifikasi dengan memberikan suku awal yang cukup untuk membentuk suatu pola, dengan rumus eksplisit 
untuk suku ke- $n$ atau oleh rumus rekursi (Varberg \& Purcell, 1987).

Selain itu, susunan-susunan bilangan real tersebut juga tidak memenuhi definisi barisan bilangan, yaitu barisan bilangan real adalah fungsi yang didefinisikan pada himpunan semua bilangan asli $\mathbb{N}$ dengan daerah hasilnya termuat dalam himpunan semua bilangan real (Manuharawati, 2013).

\section{Kesimpulan}

Dari pembahasan di atas, disimpulkan bahwa beberapa elemen konstruksi pada atap Lopo yang dianalisis secara matematis menunjukkan adanya konsep susunan bilangan real. Jenis susunan bilangan real yang dimaksud antara lain: Susunan bilangan real yang monoton turun, susunan bilangan real terbatas, susunan bilangan real dengan selisih tetap dan susunan bilangan real dengan selisih tidak tetap. Susunan bilangan real yang monoton turun dan terbatas dapat ditunjukkan dengan suku pada susunan bilangan tersebut yang semakin mengecil, ini disebabkan bentuk Lopo yang mengerucut dan semakin mengecil ke satu titik pada bubungan atap. Susunan bilangan real dengan selisih tidak tetap ditunjukkan pada semua elemen yang dianalisis, sedangkan susunan bilangan real dengan selisih tetap hanya ditunjukan pada barisan yang terbentuk dari diameter lingkaran luar.

Perbedaan-perbedaan yang ditemukan dalam penelitian ini disebabkan karena pemahaman masyarakat dalam membangun Lopo yang berbentuk kerucut hanya didasarkan pada nilainilai budaya sehingga pengukuran dilakukan secara tidak tetap sesuai dengan model kerucut yang sesungguhnya, dalam hal ini Lopo tidak dikerjakan dengan perhitungan matematis yang tetap sehingga jarak dari beberapa elemen (lingkaran luar, lingkaran dalam, dan sebagainya) tidak selalu sama, atau dengan kata lain dapat dikatakan bahwa ukuran-ukuran dalam matematika tidak diperhatikan secara detail sehingga beberapa elemen tidak pada ukuran yang sebenarnya. Secara umum dapat disimpulkan bahwa dalam arsitektur tradisional, matematika tidak diterapkan secara utuh, karena masyarakat lebih menekankan pada nilai-nilai budaya dan unsur estetika.

Hasil penelitian ini dapat dijadikan sebagai panduan desain pada konstruksi bangunan Lopo lainnya, baik itu Lopo pada Benteng None atau Lopo pada tempat lainnya. Selain itu, penelitian ini dapat dilanjutkan dengan meneliti atau melihat dari sudut pandang yang berbeda.

\section{Daftar Pustaka}

Benu \& Rafael. (2019). Perubahan perspektif rumah Lopo (uim lopo) pada masyarakat Atoin Meto di Desa Nusa Kecamatan Amanuban Barat Kabupaten Timor Tengah Selatan. SALAM; Jurnal Sosial \& Budaya Syar-i, Vol. 6, No. 3, 281-292.

Lakapu \& Lapenangga. (2019). Eksplorasi etnomatematika dalam konstruksi Lopo dan Ume Kbubu. Prosiding Seminar Vista. Kupang: UNWIRA.

Manuharawati. (2013). Analsis real 1. Sidoarjo: Zifatama.

Salamah. (2019). Berlogika dengan Matematika 2. Solo: Tiga Serangkai Pustaka Mandiri.

Saraswati. (2016). Bangunan adat Timor di Desa Maslete dan Desa Boti. Yogyakarta: K-Media. 
ATRIUM, Vol. 6, No. 1, Mei 2020, 11-22

Varberg, D. \& Purcell, E.J. (1987). Kalkulus dan geometri analitis jilid 1. Jakarta: Erlangga.

Varberg, D. \& Purcell, E.J. (2010). Kalkulus jilid 2. Tangerang: Binarupa Aksara. 